\title{
NUISANCE DUST FALL-OUT MONITORING IN THE VICINITY OF KELVIN POWER STATION
}

\author{
W J M Hamman \\ Environmental Pollution Prevention Branch Environmental Health Department \\ Health, Housing and Urbanisation Directórate Johannesburg City Council, P O Box 1477, Johannesburg 2000
}

\section{BACKGROUND}

During a meeting of the National Association for Clean Air held in Kempton Park in 1990, complaints about nuisance dust in the residential areas adjacent to Kelvin Power Station were raised by the residents. As a result a bucket system based on standard deposition gauges ${ }^{3,4}$ to determine the average daily dust deposition rate was initiated in July at six sites in the vicinity of the power station by the Environmental Health Department's Environmental Pollution Prevention Branch.

\section{COLLECTION AND ANALYSIS OF DATA}

Dust fall-out is collected in 5 litre cleaned plastic buckets, filled to one-fourth volume with water and mounted 2,53,0 metres above ground level on street light poles by means of a metal clamp.

Samples were collected on a weekly basis over the period 6 July 1990 to 25 February 1993 and the total hours of sample collection noted. A lid was placed on the bucket during transportation of the sample. The collected fall-out was quantified by thoroughly stirring the bucket contents to mobilise all particles and then filtering the mixture of each bucket under vacuum through pre-weight glass fibre filters. The filters were then dried and collected fall-out re-weighed, the difference in weight being equal to the total fall-out. Results are expressed as grams per square metre per day of fall-out ( $\mathrm{gr} / \mathrm{m}^{2} /$ day), the surface area of the sampling bucket mouth being taken into account.

In order to improve the data base on precipitation levels in the area, a further eleven sites were added after applying the Kriging technique ${ }^{s}$ to the collected data. Assistance with sample collection at the additional sites was provided by Edenvale and Kempton Park Health Departments.

Average dust deposition concentration, categorised as indicated in Table $1^{1}$, were determined for each sampling period and presented on a scaled diagram of the area.

Table 1. Dust fall-out (deposition)

\begin{tabular}{||c|c|}
\hline Category & concentration $\left(\mathrm{gram} / \mathrm{m}^{2} /\right.$ day $)$ \\
\hline Slight & 0,25 to 0,5 \\
Moderate & 0,25 to 1,2 \\
Heavy & $0,5>1,2$ \\
Very heavy & $>1,25$ \\
\hline
\end{tabular}

In February 1991 a sprinkling system was purchased to control the dust blown off the ash dams and commissioned the end of July 1991. Deposition dust levels before and after the introduction of the sprinkling system were compared and are summarised in Table 2.

\section{RESULTS SUMMARY}

Table 2. Dust precipitation categories, in percentages, before and after commencement of sprinkler system

\begin{tabular}{|c|c|c|c|c|c|c|c|c|}
\hline $\begin{array}{c}\text { Monitoring } \\
\text { site }\end{array}$ & \multicolumn{2}{|c|}{$\boldsymbol{A}$} & \multicolumn{2}{|c|}{ c } & \multicolumn{2}{|c|}{ D } & \multicolumn{2}{|c|}{ E } \\
\hline Categcry & Before & After & Before & After & Beforo & After & Before & After \\
\hline $\begin{array}{r}\text { slight } \\
\text { Moderate } \\
\text { Beavy } \\
\mathrm{v} \text { Beavy } \\
\end{array}$ & $\begin{array}{r}73.1 \\
19.2 \\
7.7 \\
0.0 \\
\end{array}$ & & $\begin{array}{l}16.7 \\
16.7 \\
33.3 \\
33.3 \\
\end{array}$ & $\begin{array}{r}62.0 \\
28.2 \\
8.5 \\
1.4 \\
\end{array}$ & $\begin{array}{r}40.0 \\
42.9 \\
14.3 \\
2.9 \\
\end{array}$ & $\begin{array}{r}44.6 \\
43.1 \\
12.3 \\
0.0 \\
\end{array}$ & $\begin{array}{r}41.9 \\
44.2 \\
9.3 \\
4.7 \\
\end{array}$ & $\begin{array}{r}49.3 \\
43.5 \\
7.2 \\
0.0 \\
\end{array}$ \\
\hline $\begin{array}{c}\begin{array}{c}\text { Monitoring } \\
\text { site }\end{array} \\
\end{array}$ & \multicolumn{2}{|c|}{$F$} & \multicolumn{2}{|c|}{ G } & \multicolumn{2}{|c|}{ B } & \multicolumn{2}{|c|}{ I } \\
\hline category & Before & After & Before & After & Before & After & Before & After \\
\hline $\begin{array}{r}\text { slight } \\
\text { Moderate } \\
\text { Beavy } \\
\text { V Heavy } \\
\end{array}$ & $\begin{array}{r}6.1 \\
24.2 \\
30.3 \\
39.4 \\
\end{array}$ & $\begin{array}{r}22.5 \\
56.3 \\
21.1 \\
0.0 \\
\end{array}$ & $\begin{array}{r}61.4 \\
31.8 \\
6.8 \\
0.0 \\
\end{array}$ & $\begin{array}{r}73.8 \\
23.8 \\
2.4 \\
0.0 \\
\end{array}$ & $\begin{array}{r}87.5 \\
6.3 \\
6.3 \\
0.0 \\
\end{array}$ & $\begin{array}{r}69.4 \\
22.6 \\
8.1 \\
0.0 \\
\end{array}$ & $\begin{array}{r}66.7 \\
22.2 \\
11.1 \\
0.0 \\
\end{array}$ & $\begin{array}{r}43.8 \\
46.6 \\
9.6 \\
0.0 \\
\end{array}$ \\
\hline $\begin{array}{c}\text { Monitoring } \\
\text { site }\end{array}$ & \multicolumn{2}{|c|}{$\mathrm{J}$} & \multicolumn{2}{|c|}{$\mathbf{x}$} & \multicolumn{2}{|c|}{ L } & \multicolumn{2}{|c|}{$x$} \\
\hline Category & Before & After & Before & After & Before & After & Before & After \\
\hline $\begin{array}{r}\text { slight } \\
\text { Moderste } \\
\text { Beavy } \\
\mathrm{v} \text { Beavy } \\
\end{array}$ & $\begin{array}{r}84.2 \\
15.8 \\
0.0 \\
0.0 \\
\end{array}$ & $\begin{array}{r}73.3 \\
20.0 \\
6.7 \\
0.0 \\
\end{array}$ & $\begin{array}{r}82.4 \\
5.9 \\
11.8 \\
0.0 \\
\end{array}$ & $\begin{array}{r}68.5 \\
24.7 \\
6.8 \\
0.0 \\
\end{array}$ & & $\begin{array}{r}75.0 \\
19.1 \\
5.9 \\
0.0 \\
\end{array}$ & & $\begin{array}{r}50.7 \\
37.7 \\
11.6 \\
0.0 \\
\end{array}$ \\
\hline $\begin{array}{c}\text { Monitoring } \\
\text { site } \\
\end{array}$ & \multicolumn{2}{|c|}{$\mathrm{N}$} & \multicolumn{2}{|c|}{0} & \multicolumn{2}{|c|}{$\mathbf{P}$} & \multicolumn{2}{|c|}{0} \\
\hline Category & Before & After & Before & After & Before & After & Before & After \\
\hline $\begin{array}{r}\text { slight } \\
\text { Moderate } \\
\text { Beavy } \\
\mathrm{v} \text { Boavy } \\
\end{array}$ & $\begin{array}{r}92.3 \\
7.7 \\
0.0 \\
0.0 \\
\end{array}$ & $\begin{array}{r}56.7 \\
26.7 \\
16.7 \\
0.0 \\
\end{array}$ & $\begin{array}{r}46.2 \\
38.5 \\
15.4 \\
0.0\end{array}$ & $\begin{array}{r}25.0 \\
25.0 \\
50.0 \\
0.0 \\
\end{array}$ & $\begin{array}{r}81.3 \\
18.8 \\
0.0 \\
0.0 \\
\end{array}$ & $\begin{array}{r}34.4 \\
43.8 \\
21.9 \\
0.0 \\
\end{array}$ & $\begin{array}{r}80.0 \\
6.7 \\
13.3 \\
0.0\end{array}$ & $\begin{array}{r}56.3 \\
31.2 \\
9.4 \\
3.1 \\
\end{array}$ \\
\hline
\end{tabular}

\section{TREND ANALYSIS}

The Mann-Kendall nonparametric test for trend ${ }^{2}$, which uses only the relative magnitude of the data rather than actual measured values, was applied to the entire data set, ie from 6 July 1990 to 25 February 1993 as well as comparisons of before and after the introduction of the sprinkling system.

\section{DISCUSSION OF RESULTS}

Only those sites within 800 meters of the power station property boundary (sites C, E and F see Table 2) were likely to have been substantially influenced by dust blown off the power station's ash dams, and showed a highly significant reduction in nuisance dust levels subsequent to the introduction of the sprinkling system.

Three other sites located at approximately $8 \mathrm{~km}$ from the Power Station's ash dams (sites H, L and M see Tablc 2) showed a moderate reduction in nuisance dust levels, which might also be attributed to the effects of the sprinkling system. 
Although the results at a site $11 \mathrm{~km}$ away from the ash dams, showed a highly significant positive trend (sites $\mathrm{J}$ see Table 2), as well as, to a lesser extent, a site $5 \mathrm{~km}$ north of the power station (sites $P$ see Table 2), the values measured to date are not a cause for undue concern as the results fall into the categories referred to in Table 1 namely slight to moderate.

\section{CONCLUSIONS}

The program described above is a low technology and cost effective method of monitoring nuisance dust deposition in the environment.

From the results of the nuisance dust measuring programme it appears that the sprinkling system installed to limit dust blown off the ash dams has had a marked effect in mitigating nuisance dust levels in areas adjacent to the Power Station property.

\section{ACKNOWLEDGEMENTS}

The author would like to thank to the following :

Johannesburg Electricity Department for the opportunity to undertake this study,
Staff members Mr M Clark and Mr H Krohm as well as the Edenvale and Kempton Park Health Departments for detailed work undertaken by them on the project, and

Prof H J Annegarn (Annegarn Environmental Research) for the valuable guidance on techniques used in similar studies done by him.

\section{REFERENCES}

1. The Clean Air Journal of the National Association for Clean Air, Vol 8, No 3, May 1991.

2. Gilbert R.O., Statistical Methods for Environmental Pollution Monitoring, Van Nostrand Reinhold New York 1987.

3. Tentative Methods of analysis for dust fall from the Atmosphere (Method in Air Sampling and Analysis, 1972, Inter Society Committees).

4. Hall D and Walters R. An Improved, Readily Available Dustfall Gauge, (1986), Atmospheric Environment Vol 20 No 1.

5. Gilbert R.O. and J.C. Simpson, 1985. Kriging from estimating spatial pattern of contaminants: Potential and problems, Environmental Monitoring and Assessment 5 : 113-135. 